\title{
Influence of black tea fractions addition on dough characteristics, textural properties and shelf life of wheat bread
}

\author{
Alina Culetu ${ }^{1, *}$, Denisa Eglantina Duta ${ }^{1}$, Wilfried Andlauer ${ }^{2}$ \\ ${ }^{1}$ National Institute of Research \& Development for Food Bioresources - IBA Bucharest, Dinu \\ Vintila 6, 021102, Bucharest, Romania \\ ${ }^{2}$ Institute of Life Technologies, University of Applied Sciences and Arts Western Switzerland, \\ HES-SO, Route du Rawyl 47, CH-1950 Sion, Switzerland \\ * Corresponding author: Tel./fax: +40 3162058 33, E-mail: alinaculetu@gmail.com; \\ alina.culetu@bioresurse.ro
}

\begin{abstract}
Theanine (T) and polyphenols (P) enriched fractions obtained from decaffeinated black tea dust by fractionation on a XAD resin, were incorporated into wheat bread formulation. The effect on dough properties and quality characteristics of supplemented breads was investigated. The development time and mixing resistance of dough was significantly increased by $\mathrm{P}$ fraction addition, indicating a stronger dough structure. $\mathrm{P}$ inhibited the Gram-positive bacteria, while $E$. coli was only inhibited by $\mathrm{T}$ fraction. Addition of $\mathrm{P}$ fraction provided an extension of bread shelf life up to 4 days as compared to control bread, while $\mathrm{T}$ fraction increased shelf life for 1 day. $\mathrm{P}$ fraction hindered the retrogradation of amylopectin which had no antifirming effect in bread. During storage, starch retrogradation in $\mathrm{P}$ bread crumbs was significantly retarded as compared with the control. P fraction produced darker, harder and coarser crumb structure and lower loaf volume. Crumb hardness was negatively correlated with bread volume $(r=-0.90, p<0.05)$. The electronic nose system discriminated the bread odour based on the fraction used. Bread samples of different storage times were distinguished by e-nose with discrimination index above 90 .
\end{abstract}

Keywords: bread shelf life; tea fractions; dough mixing properties; texture; retrogradation; electronic nose. 


\section{Introduction}

Bread is a widely consumed food product with an average consumption of $50 \mathrm{~kg}$ of bread per person per year in most of the EU countries [1]. Bread is characterized by relatively short shelf life. Besides microbiological spoilage, different physico-chemical changes occur in bread during storage, known as bread staling. Bread staling is a complex phenomenon in which multiple mechanisms take place [2]. The consequences of bread staling includes: loss of flavour or changes of aroma compounds, changes in bread texture such as dryness and firming of the crumb, loss of crispness of the crust and elasticity decrease, changes in moisture content, moisture migration within the product, redistribution of water among components as well as possible interactions between starch and gluten [2-4]. In general, the staling process is attributed to the retrogradation of starch, specifically of the short amylopectin side chains [2].

Different approaches were used to improve the bread shelf life and staling, such as improvement of packaging techniques [5], addition of different types of enzymes [6], hydrocolloids [7] or addition of plants bioactive compounds with antioxidant activity [8]. Worldwide, tea has received an increased interest due to its biologically active components [9]. Black tea is rich in various antioxidant polyphenols such as catechins, theaflavins and thearubigins, and nutrients including amino acids and minerals. Black tea has promising health benefits as natural antioxidant, anti-carcinogenic and antimicrobial agent, acting against cardiovascular disorders and cancer [10, 11]. Recently, tea polyphenols have been incorporated in various bakery products for nutritional benefits and the potential to prolong shelf life [12-15].

Black tea dust, a by-product from the black tea decaffeination process, is a very fine powder (particle size lower than $1 \mathrm{~mm}$ ) that was shown to represent a source of valuable components [16]. In a previous work, the effect of theanine and polyphenols enriched fractions from decaffeinated black tea dust on the formation of Maillard reaction products and sensory attributes of breads was investigated [17]. The authors found that both fractions acted as antiglycative agents following different mechanisms of actions and inhibited fluorescent advanced glycation end-products formation.

The aim of the present study was to investigate the effect of the theanine and polyphenols enriched fractions from black tea, obtained by fractionation on a XAD-16 resin, on dough properties and quality characteristics of supplemented breads. The changes in textural and starch retrogradation properties of bread during storage at room temperature were compared with a non-supplemented wheat bread as control. Microbiological shelf life of the formulated breads was determined. Moreover, the impact on the headspace aroma changes during bread storage by electronic nose system was explored.

\section{Materials and methods}

\section{Materials}

Aqueous tea fractions, theanine (T) and polyphenols (P) enriched fraction, respectively, were prepared from decaffeinated black tea dust, by fractionation on a XAD-16 resin, as reported in previous studies $[16,17]$. $\mathrm{T}$ fraction contained all free amino acids present in tea (among them, theanine with a content of $1.6 \mathrm{mg} / \mathrm{mL}$ ), sugars (sucrose $1.4 \mathrm{mg} / \mathrm{mL}$, glucose $5.3 \mathrm{mg} / \mathrm{mL}$, fructose $4.7 \mathrm{mg} / \mathrm{mL})$ and very polar phenolic compounds such as gallic acid $(1 \mathrm{mg} / \mathrm{mL})$. P fraction contained catechin $0.14 \mathrm{mg} / \mathrm{mL}$, chlorogenic acid $0.19 \mathrm{mg} / \mathrm{mL}$, ECG (epicatechin gallate) 0.29 $\mathrm{mg} / \mathrm{mL}$, EGCG (epigallocatechin gallate) $0.17 \mathrm{mg} / \mathrm{mL}$ and rutin $0.84 \mathrm{mg} / \mathrm{mL}$ [17]. 
The total polyphenol content (TPC), in mg gallic acid equivalents (GAE) per $\mathrm{mL}$ of the fractions used in this study was $2.61 \pm 0.03 \mathrm{mg} / \mathrm{mL}$ for $\mathrm{T}$ and $11.21 \pm 0.25 \mathrm{mg} / \mathrm{mL}$ for $\mathrm{P}$, respectively. The antioxidant capacity was estimated as $5.64 \pm 0.14 \mathrm{mg}$ Trolox $/ \mathrm{mL}$ for $\mathrm{T}$ and $15.83 \pm 0.58 \mathrm{mg}$ Trolox/mL for $\mathrm{P}$, respectively. Commercially available white wheat flour, salt and baking yeast were used for the study.

\section{Antimicrobial activity of the fractions}

Antimicrobial activity of the tea enriched fractions was analyzed as recommended by the Clinical and Laboratory Standards Institute [18]. The microorganism strains were Gram-positive bacteria (Bacillus cereus ATCC 11778, Staphylococcus aureus ATCC 25923, Bacillus spizizenii ATCC 6633), Gram-negative bacteria (Escherichia coli ATCC 25922) and fungal strain (Aspergillus brasiliensis ATCC 16404). All microorganisms were grown at $37^{\circ} \mathrm{C}$ in Tryptic Soy Broth for $18 \mathrm{~h}$. Suspensions of microorganisms (inoculum) were adjusted to $10^{3} \mathrm{CFU} / \mathrm{mL}$ through decimal dilutions in peptone saline. Fifteen $\mathrm{mL}$ of Plate Count Agar were poured in Petri plates followed by solidification for $30 \mathrm{~min}$. The solidified medium was inoculated with $100 \mu \mathrm{L}$ inoculum which was spread over the plate and rested for $30 \mathrm{~min}$. Then, sterile blank discs $(6$ $\mathrm{mm}$ ) were impregnated with $10 \mu \mathrm{L}$ of each tea fraction and the discs were inserted into the plates. The plates were incubated at $37^{\circ} \mathrm{C}$ for $24 \mathrm{~h}$ for the bacteria and at $25^{\circ} \mathrm{C}$ for 7 days for the fungus. After the incubation period, inhibition zones formed in the medium were measured as transparent zone around each disc. Values reported were average of three determinations.

\section{Dough mixing properties by Mixolab}

The effect of tea fractions on the thermo-mechanical properties of wheat flour was evaluated using a Mixolab analyzer (Chopin Technologies, Villeneuvela-Garenne, France). Required amount of water calculated by Mixolab software (version 4.0.8) according to input values of flour moisture and water absorption was manually added. The amount of water was partially $(50 \%)$ or integrally $(100 \%)$ substituted with $\mathrm{T}$ and $\mathrm{P}$ aqueous fraction, respectively. Tea fractions were manually added into the Mixolab bowl.

All measurements were performed using the "Chopin+" protocol [19]. Instrumental settings were: initial mixing at $30{ }^{\circ} \mathrm{C}$ for $8 \mathrm{~min}$, heating to $90{ }^{\circ} \mathrm{C}$ with $4{ }^{\circ} \mathrm{C} / \mathrm{min}$, maintaining at $90{ }^{\circ} \mathrm{C}$ for $7 \mathrm{~min}$, cooling to $50{ }^{\circ} \mathrm{C}$ at $4{ }^{\circ} \mathrm{C} / \mathrm{min}$ cooling rate and holding for $5 \mathrm{~min}$ at $50{ }^{\circ} \mathrm{C}$. The mixing speed during the measurement was $80 \mathrm{rpm}$. Data from three determinations were averaged.

\section{Baking procedure}

Table 1 displays the formulations of wheat bread production. White wheat flour was mixed with tea fractions/water suspension containing salt and compressed fresh yeast. The dough was mixed in a Diosna mixer with kneading arm of a L-shape (Diosna Original, Dierks \& Söhne, Maschinenfabrik, Osnabrück, Germany) for $1 \mathrm{~min}$ at low speed (first step) and for 5 min at high speed (second step). After resting for $30 \mathrm{~min}$, the dough was divided into $150 \mathrm{~g}$ pieces and then rounded and introduced in the baking shapes. The dough was proofed at $36{ }^{\circ} \mathrm{C}$ for $45 \mathrm{~min}$ (M.C.E. Meccanica, model DAT TECH 1, Buttapietra, Italy) and baked at $220{ }^{\circ} \mathrm{C}$ for $25 \mathrm{~min}$ with steam at start in an oven (Mondial Forni, Verona, Italy). Breads were removed from the pans, cooled for $2 \mathrm{~h}$ prior analysis (day 0 , fresh bread) and then stored in cast polypropylene bags 
at room temperature until visible microbial spoilage. One batch was prepared for each bread formulation.

\section{Physical-chemical analysis of bread}

Bread volume was determined by rapeseed displacement method [20]. For crumb porosity measurements (determined by the ratio of pores volume to total volume of a known volume of crumb), a cylindrical piece of crumb was cut from a $60 \mathrm{~mm}$ slice taken from the centre of the bread loaf and weighed [21].

Moisture content of bread crumb was analyzed by the oven drying method [22] and water activity was measured at $25{ }^{\circ} \mathrm{C}$ with help of the Hygrolab instrument (Rotronic, USA).

Total polyphenol content in bread samples was determined according to Culetu et al. [17]. Values reported for all the above parameters were average of three determinations.

The colour intensity of bread crumb was analyzed using Chroma Meter CR-410 (Konica Minolta Sensing, Inc., Osaka, Japan) with a D65 illuminant and a $2^{\circ}$ observer angle. The colour was determined on 10 different points on the same slice $(20 \mathrm{~mm}$ thickness) taken from the centre of the loaf and it was expressed in terms of L* (lightness), $\mathrm{a}^{*}$ (redness) and $\mathrm{b}^{*}$ (yellowness) average values. Before measurements, the instrument was calibrated against the white tile.

\section{Digital image analysis of bread}

Digital images of crumb were done on $20 \mathrm{~mm}$ thick slices taken from the central part of the loaf, using a scanner (Sharp MX-2614) with 600 dpi resolution. The scanned colour images were converted to gray scale and they were analyzed using ImageJ Software 1.50i (National Institutes of Health, USA). Using bars of known lengths, pixel values were transformed into distance units. After cropping the largest possible rectangular cross-section of the bread slice, the Otsu's threshold algorithm was applied to differentiate gas cells from non-cells [23]. The results were evaluated with respect to cell density (number of cells per $\left.1 \mathrm{~cm}^{2}\right)$, average cell size $\left(\mathrm{mm}^{2}\right)$ and cell uniformity (the ratio between the number of cells lower than $5 \mathrm{~mm}^{2}$ to the number of cells higher than $5 \mathrm{~mm}^{2}$ ). Values reported were average of three determinations.

\section{Texture analysis of bread}

The texture properties of crumb were determined with an Instron Texture Analyzer equipped with a $50 \mathrm{~N}$ load cell (model 5944, Illinois Tool Works Inc., USA) following the approch of Ning et al. [12]. Bread slices of $20 \mathrm{~mm}$ thickness were cut from the centre of the loaves. A double compression test using a $40 \mathrm{~mm}$ diameter cylindrical probe was performed with penetration to $50 \%$ of sample original height at speed rate of $100 \mathrm{~mm} / \mathrm{min}$. Between compression, a resting time of $10 \mathrm{~s}$ was applied. The textural parameters calculated were hardness, springiness, cohesiveness and chewiness [24]. The average values for three determinations were reported. Texture analysis was done on each bread slice after storage until microbiological spoilage. 


\section{Differential scanning calorimetry of bread crumb}

Differential scanning calorimetry was carried out on bread crumb using DSC 8000 (Perkin Elmer, Waltham, MA, USA) which was calibrated with indium. The method was based on the procedure described by Gerits et al. [25]. Fresh (day 0) and stale crumbs at various aging time obtained from the central part of the bread were freeze-dried (Heto PowerDry PL3000, Thermo Fisher Scientific, Waltham, USA). The dried crumbs were grounded and $10 \mathrm{mg}$ were weighed in stainless steel pans and distilled water was added at a ratio of 1:3. The pans were sealed and left overnight at room temperature. The samples were heated from 20 to $120{ }^{\circ} \mathrm{C}$ with $10{ }^{\circ} \mathrm{C} / \mathrm{min}$ with nitrogen flushing $\left(20 \mathrm{~cm}^{3} / \mathrm{min}\right)$ together with an empty reference pan. The endothermic enthalpy was determined from the peak area and it was used as an index of starch retrogradation that occured on staling. Data from two determinations were averaged.

\section{Headspace-electronic nose measurements}

An e-nose system (FOX 4000, Alpha M.O.S., Toulouse, France), which consists of an array of 18 different metal oxides sensors, an HS100 autosampler and data processing software (Alpha Soft version 8.0) was used to analyze the overall volatile composition of bread samples at various aging time [26].

Crumb samples were accurately weighed to $2 \mathrm{~g}$ and placed in a $10 \mathrm{~mL}$ sealed headspace vials. Each vial was incubated under agitation $(500 \mathrm{rpm})$ at $35{ }^{\circ} \mathrm{C}$ for $600 \mathrm{~s}$ for headspace volatile generation. Then, $1500 \mu \mathrm{L}$ of the bread headspace was injected by the autosampler into the measuring chamber. Carrier gases used were synthetic air and nitrogen with a flow rate of 150 $\mathrm{mL} / \mathrm{min}$. The acquisition time was $120 \mathrm{~s}$. A flushing step for $120 \mathrm{~s}$ was applied to clean the sensors between samples. Three determinations were performed for each sample and the individual signals recorded were used for statistical analysis. Principal Component Analysis (PCA) was used in order to detect the differences in volatile composition among samples and discrimination index was calculated by the software (higher is the discrimination index, better is the discrimination).

\section{Microbiological analysis}

Ten $\mathrm{g}$ of bread was homogenized with $90 \mathrm{~mL}$ peptone saline solution (Oxoid, Basingstoke, Hampshire, England), obtaining a dilution of $10^{-1}$. This solution was used to obtain other dilutions $\left(10^{-2}\right)$. An aliquot of $0.1 \mathrm{~mL}$ from each dilution was spread on MEYP Agar and Dichloran Rose Bengal Chloramphenicol Agar (Biokar Diagnostics, Zac de Ther, France) for Bacillus cereus count and yeasts and moulds count, respectively. Inoculated Petri plates were incubated at $30{ }^{\circ} \mathrm{C}$ for $48 \mathrm{~h}$ (for B. cereus count) [27] and at $25^{\circ} \mathrm{C}$ for 5 days (for yeasts and moulds count) [28]. After incubation, the results of the counts were expressed as CFU (colony forming units)/g of bread. Determinations were carried out in triplicate.

\section{Statistical analysis}

Results of all parameters were expressed as mean \pm standard deviation (SD). One-way ANOVA followed by Tukey test was applied to determine differences between means using the 
Minitab $^{\circledR} 17$ software (Minitab Ltd., UK). Differences were considered to be significant at $p<$ 0.05 .

\section{Results and discussions}

\section{Antimicrobial activity of the tea fractions}

Tea polyphenols have been found to possess antimicrobial activities such as antibacterial, antiviral and antifungal effects [29]. Teas and tea extracts are a rich source of antimicrobial agents [30].

In the present study, Gram-positive bacteria were inhibited only by $\mathrm{P}$ fraction. The strain of $S$. aureus was the most sensitive, showing the largest inhibition diameter in the presence of $\mathrm{P}$ fraction $(14.0 \pm 1.0 \mathrm{~mm})$. Strains of $B$. cereus and $B$. spizizenii were less sensitive, with diameters of the inhibition zone of $8.5 \pm 0 \mathrm{~mm}$ and $7.5 \pm 1.0 \mathrm{~mm}$, respectively. These results are in-line with those of Sari et al. [31]. They showed that the black tea extracts had strong antimicrobial activity and $S$. aureus was found to be the most sensitive, while E. coli was the most resistant among the bacterial strains studied. Epigallocatechin gallate (EGCG) was found to be the most effective antimicrobial tea polyphenol and Gram-positive bacteria were more susceptible towards EGCG compared to Gram-negative strains [29]. Also, Arora et al. [32] showed that Gram-positive bacteria were comparatively more sensitive to tea than Gramnegative bacteria due to differences in their cell wall structure.

T fraction was not active against B. cereus, S. aureus and B. spizizenii. E. coli was only inhibited by $\mathrm{T}$ fraction (inhibition zone: $6.7 \pm 0.6 \mathrm{~mm}$ ). $\mathrm{T}$ fraction does not contain any catechins, but it contains others polar phenolic compounds such as phenolic acids, like gallic acid and also minerals that could have an antimicrobial activity. A. brasiliensis was resistant to both $\mathrm{T}$ and $\mathrm{P}$ fractions (no inhibition zone).

Almajano et al. [33] showed that the antimicrobial activity was strongly correlated with antioxidant activity than with TPC. The present study confirms these findings. P fraction with an antioxidant capacity of $15.83 \pm 0.58 \mathrm{mg}$ Trolox $/ \mathrm{mL}$ was a better microbiological inhibitor than $\mathrm{T}$ fraction.

\section{Effect of tea fractions on dough mixing properties}

The effect of tea fractions on wheat flour dough characteristics is shown in Table 2. Dough development time, stability time, protein weakening (C2), starch gelatinization (C3), starch gel stability (C4) and starch retrogradation (C5) were considered [34].

The 3T dough was not significantly different than control concerning dough development time. Dough development time of 6T, 3P and 6P were significantly higher $(p<0.05)$ compared with the control. Fractions composition was likely responsible for longer development time. Amino acids, sugars, gallic acid from $\mathrm{T}$ fraction or polyphenols from $\mathrm{P}$ fraction hindered gluten network development.

Stability time, representing the mixing resistance of dough, was significantly increased by $\mathrm{P}$ fraction incorporation, indicating a stronger dough structure. The significant uptrend $(p<0.05)$ in stability time of $\mathrm{P}$ doughs might be explained by the presence of polyphenols which might have less destructive influence on gluten network formation in dough. Ishii et al. [35] revealed that tea catechin EGCG can covalently bind to cysteinyl thiol groups in proteins forming EGCG- 
protein adducts. Wang and Zhou [36] reported also that during the bread making process using green tea extract, there are possible interactions between tea catechins and wheat proteins through hydrogen bonding. Ning et al. [12] reported that dough became stronger with increasing green tea powder addition. The presence of black tea polyphenols could have similar effects on the gluten network.

On the other hand, $\mathrm{T}$ fraction resulted in a decrease in dough stability and $\mathrm{C} 2$ parameter reflecting the reduced strength (a more intensive weakening) of the protein network. $\mathrm{T}$ fraction showed a softening effect by release of water molecules in the dough. Protein weakening is referred to the beginning of the protein destabilization and unfolding [37]. The decrease is caused by the presence of amino acids in the $\mathrm{T}$ fraction. A weaker protein network is caused by an increase of free thiol groups $(-\mathrm{SH})$ and reduction of disulfide bonds $(\mathrm{S}-\mathrm{S})$ in the dough [38].

A significant higher value $(p<0.05)$ for $\mathrm{C} 2$ indicated that stronger protein network was formed in the dough containing the $\mathrm{P}$ fraction. $\mathrm{P}$ fraction produced dough with strong mixing resistance in a concentration dependent manner.

$\mathrm{T}$ fraction had no significant impact $(p>0.05)$ on starch gelatinization $(\mathrm{C} 3)$ compared with the control, while, a greater degree of starch gelatinization was attributed to $\mathrm{P}$ fraction incorporated doughs (higher C3).

The stability of starch gel (C4) became higher with the addition of both types of tea fractions.

With the addition of tea fractions, C5 values were significantly higher $(p<0.05)$ compared to the control, which was an indication of an increased degree of starch retrogradation. This result could be attributed to the hydroxyl groups of the compounds from tea fractions that might have interacted with starch [39]. However, starch retrogradation became greater with $\mathrm{T}$ fraction as compared to $\mathrm{P}$ fraction addition.

Overall, the dough properties provided by Mixolab are the result of the interaction of different components from the tea fractions with the flour constituents. Polar compounds in $\mathrm{T}$ fraction and phenolic compounds with reduced polarity in $\mathrm{P}$ fraction may have different mechanisms in forming complexes with gluten or starch. Sivam et al. [40] indicated that highly polar phenolic acids (caffeic acid from kiwi) are more mobile in bread than low polarity polyphenols with high molecule weight (anthocyanins and proanthocyanins from blackcurrant and apple).

\section{Bread characteristics}

A previous study showed that theanine and polyphenols fortified breads were moderately liked by consumers with scores ranging from 5.8 to 6.1 and from 5 to 6 , respectively, in dependence with the level of fractions used in bread preparation [17]. The scores were significantly different compared to bread control only at higher level of $\mathrm{P}$ fraction used in bread making (more than $50 \%$ relative to flour).

It is known that the content of bioactive compounds is slightly reduced after baking due to their degradation. Wang and Zhou [36] reported that around $84 \%$ of the green tea catechins were retained in bread after baking. Also, theanine fortified breads lost up to $30 \%$ of theanine content after baking [16]. In this study, after baking, breads contained around 34\% lower level of TPC than the corresponding dough. The TPC value for dough samples were $1.8 \mathrm{mg} / \mathrm{g} \mathrm{d.m.} \mathrm{(3T),} 2.9$ $\mathrm{mg} / \mathrm{g} \mathrm{d.m.} \mathrm{(6T),} 4.6 \mathrm{mg} / \mathrm{g} \mathrm{d.m.} \mathrm{(3P)} \mathrm{and} 7.5 \mathrm{mg} / \mathrm{g} \mathrm{d.m.} \mathrm{(6P)} \mathrm{(Table} \mathrm{1).} \mathrm{Due} \mathrm{to} \mathrm{the} \mathrm{composition} \mathrm{of}$ the fraction added in the dough formulation, TPC increased in all breads, the values were between 2.3 and 3.9 fold higher (for 3T and 6T) and between 6.1 and 9.9 fold higher (for 3P and $6 \mathrm{P}$ ) as compared to the control (Table 3). The black tea polyphenols (for example catechins and 
theaflavins) from P fraction were responsible for the highest TPC values in fortified P breads. Moreover, the formation of Maillard products contributed to the TPC of breads [16, 17].

The physical characteristics of bread samples are summarized in Table 3 . The volume of fortified breads was lower than the control wheat bread. A ratio of $\mathrm{T}$ fraction to water of 1:1 used in bread manufacture did not significantly affect $(p>0.05)$ the bread volume compared with the control. However, a significant decrease $(p<0.05)$ in the loaf volume was observed as the level of T fraction addition increased. The use of $\mathrm{P}$ fraction also reduced significantly $(p<0.05)$ the bread volume, the decrease was in a concentration dependent manner. The higher amount of $\mathrm{P}$ fraction used decreased the bread volume by $14.5 \%$ compared to the control. Polyphenols bread samples had a resistant protein network (high $\mathrm{C} 2$, Table 2), hindering the dough from developing and producing a smaller bread. The addition of tea fractions resulted in a decreased dough rise. The reduced volume may be caused by physical and chemical interactions among gluten and the components from fractions. The results are in agreement with other findings reported previously on the effect of green tea powder on bread volume [12].

Regarding bread crumb porosity, the addition of $\mathrm{P}$ fraction determined a significant $(p<0.05)$ decrease compared with control bread.

Table 3 contains also the colour parameters of bread crumb samples. L* value significantly decreased $(p<0.05)$ with the fraction addition. This means that the crumbs containing the fractions had a darker colour than the control (Fig. 1). Polyphenols bread exhibited the darkest colour due to the higher polyphenol content. The $\mathrm{a}^{*}$ values of the crumb significantly increased $(p<0.05)$ relative to the fractions addition. This was attributed to the formation of a reddish colour as the percentage of both fractions increased in the formulation. The yellowness ( $\left.b^{*}\right)$ of the crumb was significantly different $(p<0.05)$ between all samples. P breads had significantly lower value for $b^{*}$ parameter, indicating a less yellow appearance, while $T$ breads were significantly higher than the control.

Visual characteristics of crumb are elements of the quality of the final product. Image analysis of bread slices scanned is presented in Fig. 1, while crumb characteristics obtained from the analysis of digitalized images are listed in Table 3. Significantly lower number of cells $/ \mathrm{mm}^{2}(p<$ 0.05) compared to control obtained for $6 \mathrm{P}$ and $3 \mathrm{P}$ breads was associated with higher cell size. The smaller cell density observed on 6P, 3P and 6T samples gave information about a coarser crumb structure as compared to control. The highest level in cell density for control denoted a finer crumb structure.

Uniformity (small/big cells ratio) showed the lowest values in polyphenols incorporated breads (3P and $6 \mathrm{P}$ ), indicating that the percentage of cells greater than $5 \mathrm{~mm}^{2}$ is higher compared with the other crumbs. In these breads, the presence of bigger cells could be explained by the fact that $\mathrm{P}$ dough was less resistant to a rise in gas pressure during fermentation. This result is supported by the lower volume of polyphenols fortified breads and a good correlation $(r=0.84, p<0.05)$ between cell density and bread volume was found.

The moisture content of the crumb was not significantly $(p>0.05)$ affected by the addition of tea fractions (Table 3). During storage, moisture content of bread crumbs decreased, but no significant differences were observed between all the samples at the same day of storage. The decrease is explained by the water migration from the wetter crumb towards the drier crust [4]. Thus, as a consequence of moisture migration, the starch-gluten interactions and bread firming are accelerated. After 2 days of storage, moisture in all crumbs decreased to $42 \%$. Samples stored for 4 days diminished their moisture up to $14 \%$ with respect to fresh breads. 
Addition of tea fractions did not significantly affect $(p>0.05)$ the water activity of crumbs. At day $0, \mathrm{a}_{\mathrm{w}}$ value was 0.94 . During storage, water activity is maintained at an almost constant level. It was a difference in water activity about $2 \%$ between day 0 and day 8 for polyphenols breads.

\section{Texture properties during bread storage}

Changes in the texture parameters of bread crumbs during storage are presented in Fig. 2. Significant differences were observed between storage days and between samples $(p<0.05)$. Fresh crumb hardness in control and 3T breads were significantly $(p<0.05)$ lower with respect to $6 \mathrm{~T}$ and polyphenols breads. Fraction $\mathrm{P}$ showed a more pronounced effect than fraction $\mathrm{T}$ on bread hardness; the increase in hardness was dose-dependent. According to the level of $\mathrm{P}$ fraction used in bread formulation, the hardness values were between 1.8 and 2.6 fold higher than the control bread. The highest values for crumb hardness might be explained by the lower volume of polyphenols breads. Correlation analysis showed that crumb hardness was highly negatively correlated with bread volume $(r=-0.90, p<0.05)$. The results are in agreement with other studies [14, 41]. In addition, a correlation between C2 (Table 2) and hardness of bread was observed $(r=0.78, p<0.05)$.

Similar to hardness, the bread chewiness gradually increased with the $\mathrm{P}$ fraction addition. There was no significant difference in springiness parameter $(p>0.05)$ between the control and fortified samples.

During bread storage, crumb hardness and chewiness gradually increased, whereas crumb springiness and cohesiveness decreased, thus, the crumb became less elastic and cohesive, irrespective of the type of fraction used. However, differences in crumb hardness between control and bread containing tea fractions became smaller and insignificant $(p>0.05)$ on day 4 of storage.

The rate of increase in hardness was higher during the first days of storage than in the following days. Crumb hardness of 6P bread on day 6 did not significantly differ $(p>0.05)$ from that of day 8 . The loss of cohesiveness from day 0 to day 4 for $\mathrm{T}$ and $\mathrm{P}$ breads was around $42 \%$ and $48 \%$, respectively.

\section{Calorimetric properies of breads}

The impact of tea fractions addition on amylopectin retrogradation in fresh and aged bread crumbs was investigated by DSC (Table 4).

Considering fresh breads (day 0), the enthalpy of retrograded amylopectin was higher in the control bread. T fraction did not significantly influence $(p>0.05)$ the retrogradation compared to control. P fraction significantly reduced the melting enthalpy of retrograded amylopectin in bread. Similar behavior was previously reported for that black tea polyphenol extract that reduced the retrogradation of rice and maize starches [42]. Also, favorable antiretrogradation effect of green tea polyphenols on the retrogradation of starches from different botanical sources were reported by Xiao et al. [43]. Tea polyphenols can interact through hydrogen bonding with starch, preventing the hydrophobic interaction of starch network for retrogradation [44].

In the stored breads, melting of formed amylopectin crystals was detected as an endothermal peak around $59{ }^{\circ} \mathrm{C}$. Melting temperatures were not affected by the type of fraction added. A significant increase of the melting enthalpy $(p<0.05)$ was observed for all breads during storage 
and this increase was more pronounced in control. Ribotta and Le Bail [45] confirmed that amylopectin retrogradation showed a gradual increment during bread staling.

During the storage period studied, retrogradation of amylopectin in T breads did not significantly differ $(p>0.05)$ from the control. Breads with $\mathrm{P}$ fractions addition exhibited lower enthalpy values than the other breads. Use of $\mathrm{P}$ fraction significantly reduced $(p<0.05)$ the extent to which amylopectin had retrograded. At day 2 of storage, the melting enthalpy in 3P and 6P breads were lower by almost $19.6 \%$ and $25.3 \%$, respectively, compared with the control. In P bread crumbs, after 6 days of storage most of the amylopectin cristals were formed and a little further increase $(p<0.05)$ in enthlapy was observed.

In this study, $\mathrm{P}$ added breads retarded the retrogradation of starch and presented the highest crumb hardness values. A highly positive correlation $(r>0.9, p<0.05)$ was noted between starch retrogradation and hardness. This is in accordance with Rogers et al. [46], where the fastest-firming bread had the slowest rate of starch retrogradation.

\section{Discrimination of bread samples by e-nose}

E-nose systems have been applied to bakery and cereal products for different purposes such as ingredient and baking stage differentiation, aging or microorganism detection [47].

Fig. 3a depicts the PCA plot which provides a map of discrimination of overall volatile composition of fresh bread samples. A good separation of samples was observed in the PCA plot and the contribution rate of $\mathrm{PC} 1$ and $\mathrm{PC} 2$ were $99.67 \%$ and $0.23 \%$, respectively. A discrimination index of 86 was achieved between control and tea fraction fortified breads which explains a very distinct odour of samples. Bread volatile formation varied according to the type of fraction used. The differences may come from aroma precursors contents in both fractions. Thus, amino acids from $\mathrm{T}$ fraction and polyphenols from $\mathrm{P}$ fraction are aroma precursors and contributes to formation of volatile compounds. In the aroma of black tea, around 500 volatile compounds, belonging to different chemical classes were identified [48]. Polyphenolic compounds, amino acids, terpenoids, alcohols and carbonyl compounds contribute to characteristic tea aroma and taste.

The volatile compound headspaces from the bread samples were also monitored during storage. Thus, for each type of bread, fresh and aged bread odour were considered. Based on PCA (Fig. 3b-f), bread samples of different storage times were well distinguished with discrimination index above 90 which indicated that a high degree of discrimination was achieved. PC1 accounted for 97.44\% (C bread), 99.10\% (3T bread), 94.82\% (6T bread), 96.37\% (3P bread) and 97.41\% (6P bread). PC1 describes the largest part of variation and represents a clear separation of samples with respect to storage time. Fresh bread samples are positioned in the opposite direction of PC1 compared to the more stored samples. Generally, bread stored for 0 and 2 days were better separated from the remaining storage times, being positioned on the bottom right of the plot. This could be because the most change in bread odour take places within the first days after baking. A trend that follows the storage time from the right side to the left side of the graph can be seen (Fig. 3b-f).

For breads stored for 2 days, the PCA provided good separation of samples with $98.73 \%$ of the variation accounted for PC1 and 1.10\% accounted for PC2 (Fig. 3g). A discrimination index of 96 was achieved for the studied samples. As for bread stored for 3 and 4 days, respectively, PCA analysis showed that bread samples $\mathrm{C}, 3 \mathrm{~T}$ and $6 \mathrm{~T}$ were grouped together (overlapped) showing that these breads became more alike in volatile composition over storage time, with no 
differentation among them (Fig. 3h-i). On the other hand, 3P and 6P breads were well separated detecting different volatile compounds, emphasising that $\mathrm{P}$ fraction is an important contributor to aroma during storage. Changes in bread odour were ascribed to the effect of storage time and to the type of fraction used. The e-nose system was sensitive to the volatile compounds from bread and was able to distiguish breads of different age and recipe.

\section{Microbiological analysis}

The packaged breads were observed daily for the manifestation of visible mould growth. Microbiological analysis of breads was performed on different days of storage. There were no differences $(p>0.05)$ in B. cereus or yeast and moulds for all bread formulations after 3 days of storage. On day 4, a visible mould growth was noticed on surface of the control bread. Also, in control bread, B. cereus was detected at day 5, when counts were $2.6 \log \mathrm{CFU} / \mathrm{g}$. B. cereus was not detected in the fortified bread samples during all points of the study investigated until day 8 .

At day 5 of storage, yeast and mould counts were below $1 \log \mathrm{CFU} / \mathrm{g}$ for the fortified breads except $3 \mathrm{~T}$ where counts were $2.5 \mathrm{log} \mathrm{CFU} / \mathrm{g}$.

At day 8, yeast and mould counts were $3.7 \log \mathrm{CFU} / \mathrm{g}$ for $3 \mathrm{P}$ and $2.2 \log \mathrm{CFU} / \mathrm{g}$ for $6 \mathrm{P}$.

$\mathrm{P}$ fraction could extend the shelf life of bread up to 4 days compared to the control, which means doubling the shelf life. The higher shelf life of polyphenols fortified breads was due to the antimicrobial activity of $\mathrm{P}$ fraction.

\section{Conclusions}

The present study provided insights into the effect of theanine and polyphenols enriched fractions, obtained from decaffeinated black tea dust by fractionation on a XAD-16 resin, on dough and bread properties during manufacturing and storage.

Mixolab analysis showed that development time and stability increased by $\mathrm{P}$ fraction incorporation in wheat flour, indicating the strengthening of the protein network.

$\mathrm{P}$ fraction acted as an antimicrobial agent inhibiting $S$. aureus, B. cereus and B. spizizenii, while E. coli was only inhibited by $\mathrm{T}$ fraction. $\mathrm{P}$ fraction maintained its efficacy on bread microbiological spoilage until day 8 of storage at room temperature. T fraction extended bread shelf life for 1 day compared to control. The type of tea fraction and concentration used have a significant effect on fresh bread volume. In particular, bread samples obtained with $\mathrm{T}$ fractions had a higher volume than samples obtained with $\mathrm{P}$ fraction. Incorporation of $\mathrm{P}$ fraction in bread formula increased crumb hardness and chewiness. However, differences in crumb hardness between control and bread containing tea fractions became smaller and insignificant on day 4 of storage. The addition of $\mathrm{P}$ fraction retarded the amylopectin retrogradation as compared with control bread.

The electronic-nose system was also able to discern the differences in bread aroma between freshly prepared and aged bread samples with a good discrimination factor (above 90) by PCA analysis. Odour volatile profiles determined by e-nose changed with respect to storage time and type of fraction used. This study supports the applicability of black tea fractions obtained from a decaffeination process as valuable food supplements for bread. 


\section{Acknowledgments}

This study was achieved through Nucleu Programme (PN 16 46), supported by the National Authority for Scientific Research and Innovation (ANCSI), contract 29N/2016. The authors wish to thank Dr. Alina Alexandra Dobre for assistance during the microbiological analysis. Authors also want to thank the Scientific Exchange Programme founded by Rectors' Conference of the Swiss Universities (CRUS, Project code: 12.030).

\section{Compliance with ethical standards}

Conflict of interest: The authors declare that they have no conflict of interest.

Compliance with ethics requirements: This article does not contain any research involving human participants and/or animals.

\section{References}

1. Collar C (2016) In: Caballero B, Finglas PM, Toldrá F (ed) Encyclopedia of Food and Health. UK, Elsevier

2. Gray JA, Bemiller JN (2003) Bread staling: molecular basis and control. Compr Rev Food Sci F 2: 1-21

3. Rayas-Duarte P, Mulvaney S (2012) In: Cauvain SP (ed) Breadmaking: Improving quality. UK, Woodhead Publishing Limited

4. He H, Hoseney RC (1990) Changes in bread firmness and moisture during long-term storage. Cereal Chem 67: 603-605

5. Galić K, Curić D, Gabrić D (2009) Shelf life of packaged bakery goods - A review. Crit Rev Food Sci 49:405-426

6. Caballero PA, Gómez M, Rosell CM (2007) Improvement of dough rheology, bread quality and bread shelf-life by enzymes combination. J Food Eng 81: 42-53

7. Guarda A, Rosell CM, Benedito C, Galotto MJ (2004) Different hydrocolloids as bread improvers and antistaling agents. Food Hydrocolloid 18: 241-247

8. Sahari MA, Asgari S (2013) Effects of plants bioactive compounds on foods microbial spoilage and lipid oxidation. Food Science and Technology 1: 52-61

9. McKay DL, Blumberg JB (2002) The role of tea in human health: An update. J Am Coll Nutr 21: 1-13

10. Sajilata MG, Bajaj PR, Singhal RS (2008) Tea polyphenols as nutraceuticals. Compr Rev Food Sci F 7: 229-254

11. Sharma V, Rao LJ (2009) A thought on the biological activities of black tea. Crit Rev Food Sci 49: 379-404

12. Ning J, Hou GG, Sun J, Wan X, Dubat A (2017) Effect of green tea powder on the quality attributes and antioxidant activity of whole-wheat flour pan bread. LWT Food Sci Technol 79: 342-348

13. Zhu F, Sakulnak R, Wang S (2016) Effect of black tea on antioxidant, textural, and sensory properties of Chinese steamed bread. Food Chem 194: 1217-1223

14. Wang R, Zhou W, Yu H-H, Chow W-F (2006) Effects of green tea extract on the quality of bread made from unfrozen and frozen dough processes. J Sci Food Agric 86: 857-864

15. Wang H, Provan GJ, Helliwell K (2000) Tea flavonoid: their functions, utilisation and analysis. Trends Food Sci Technol 11: 152-160 
16. Culetu A, Héritier J, Andlauer W (2015) Valorization of theanine from decaffeinated tea dust in bakery functional food. Int J Food Sci Tech 50: 413-420

17. Culetu A, Fernandez-Gomez B, Ullate M, del Castillo MD, Andlauer W (2016) Effect of theanine and polyphenols enriched fractions from decaffeinated tea dust on the formation of Maillard reaction products and sensory attributes of breads. Food Chem 197: 14-23

18. CLSI (2015) Performance Standards for Antimicrobial Susceptibility Testing; Twenty-Fifth Informational Supplement (M100-S25). Clinical and Laboratory Standards Institute, Wayne, Pennsylvania, USA

19. AACC Method 54-60.01. Determination of rheological behavior as a function of mixing and temperature increase in wheat flour and whole wheat meal by Mixolab. AACC International Approved Methods, $11^{\text {th }}$ edition, St. Paul, MN

20. AACC Method 10-05.01. Guidelines for measurement of volume by rapeseed displacement. AACC International Approved Methods, $11^{\text {th }}$ edition, St. Paul, MN

21. SR 91 (2007) Bread and fresh pastry products. Methods of analysis (in Romanian)

22. AACC Method 44-15.02. Moisture - Air-oven methods. AACC International Approved Methods, $11^{\text {th }}$ edition, St. Paul, MN

23. Gonzales-Barron U, Butler F (2006) A comparison of seven thresholding techniques with the $\mathrm{k}$-means clustering algorithm for measurement of bread crumb features by digital image analysis. J Food Eng 74: 268-278

24. Bourne MC (1978) Texture profile analysis. Food Technology 32: 62-66

25. Gerits LR, Pareyt B, Masure HG, Delcour JA (2015) A lipase based approach to understand the role of wheat endogenous lipids in bread crumb firmness evolution during storage. LWT Food Sci Technol 64: 874-880

26. Alpha MOS (2002) Application Note, Toulouse, France. www.alpha-mos.com

27. ISO 7932 (2004) Microbiology of food and animal feeding stuffs - Horizontal method for the enumeration of presumptive Bacillus cereus - Colony-count technique at 30 degrees $\mathrm{C}$.

28. ISO 21527-1 (2008) Microbiology of food and animal feeding stuffs - Horizontal method for the enumeration of yeasts and moulds - Part 1: Colony count technique in products with water activity greater than 0,95

29. Bansal S, Choudhary S, Sharma M, Kumar SS, Lohan S, Bhardwaj V, Syan N, Jyoti S (2013) Tea: A native source of antimicrobial agents. Food Res Int 53: 568-584

30. Siddiqui MW, Sharangi AB, Singh JP, Thakur PK, Ayala-Zavala JF, Singh A, Dhua RS (2016) Antimicrobial properties of teas and their extracts in vitro. Crit Rev Food Sci 56: 14281439

31. Sari F, Turkmen N, Polat G, Velioglu YS (2007) Total polyphenol, antioxidant and antibacterial activities of black mate tea. Food Sci Technol Res 13: 265-269.

32. Arora DJ, Kaur GJ, Kaur H (2009) Antibacterial activity of tea and coffee: Their extracts and preparations. Int J Food Prop 12: 286-294

33. Almajano MP, Carbó R, López Jiménez JA, Gordon MH (2008) Antioxidant and antimicrobial activities of tea infusions. Food Chem 108: 55-63

34. Koksel H, Kahraman K, Sanal T, Ozay DS, Dubat A (2009) Potential utilization of Mixolab for quality evaluation of bread wheat genotypes. Cereal Chem 86: 522-526

35. Ishii T, Moria T, Tanakab T, Mizuno D, Yamaji R, Kumazawa S, Nakayama T, Akagawa M (2008) Covalent modification of proteins by green tea polyphenol (-)-epigallocatechin-3-gallate through autoxidation. Free Radical Bio Med 45: 1384-1394 
36. Wang R, Zhou W (2004) Stability of tea catechins in the breadmaking process. J Agr Food Chem 52: 8224-8229

37. Rosell CM, Collar C, Haros M (2007) Assessment of hydrocolloid effects on the thermomechanical properties of wheat using the Mixolab. Food Hydrocolloid 21: 452-462

38. Joye IJ, Lagrain B, Delcour JA (2009) Endogenous redox agents and enzymes that affect protein network formation during breadmaking - A review. J Cereal Sci 50: 1-10

39. Zhu F, Cai Y-Z, Sun M, Corke H (2009) Effect of phytochemical extracts on the pasting, thermal, and gelling properties of wheat starch. Food Chem 112: 919-923

40. Sivam AS, Sun-Waterhouse D, Waterhouse GIN, Quek S, Perera CO (2011) Physicochemical properties of bread dough and finished bread with added pectin fiber and phenolic antioxidants. J Food Sci 76: H97-H107

41. Stöllman U, Lundgren B (1987) Texture changes in white bread: effects of processing and storage. Cereal Chem 64: 230-236

42. Xiao H, Lin Q, Liu G-Q, Yu F (2012) Evaluation of black tea polyphenol extract against the retrogradation of starches from various plant sources. Molecules 17: 8147-8158

43. Xiao H, Lin Q, Liu G-Q, Wu Y, Wu W, Fu X (2013) Inhibitory effects of green tea polyphenols on the retrogradation of starches from different botanical sources. Food Bioprocess Tech 6: 2177-2181

44. Zhu F (2015) Interactions between starch and phenolic compound. Trends Food Sci Technol 43: $129-143$

45. Ribotta PD, Le Bail A (2007) Thermo-physical assessment of bread during staling. LWT Food Sci Technol 40: 879-884

46. Rogers DE, Zeleznak KJ, Lai CS, Hoseney RC (1988) Effect of native lipids, shortening, and bread moisture on bread firming. Cereal Chem 65: 398-401

47. Romani S, Rodriguez-Estrada MT (2016) In: Rodríguez Méndez ML, Preedy, VR (ed), Electronic Noses and Tongues in Food Science. UK, Elsevier

48. Yashin AY, Nemzer BV, Combet E, Yashin YI (2015) Determination of the chemical composition of tea by chromatographic methods: A review. J Food Sci 4: 56-88 
Table 1 Recipe for wheat bread formulations

\begin{tabular}{|l|l|l|l|l|l|}
\hline \multirow{2}{*}{ Ingredients } & \multicolumn{3}{l|}{ Bread sample code } \\
\cline { 2 - 6 } & Bread C & Bread 3T & Bread 6T & Bread 3P & Bread 6P \\
\hline White wheat flour, g & 100 & 100 & 100 & 100 & 100 \\
\hline Compressed fresh yeast, g & 3 & 3 & 3 & 3 & 3 \\
\hline Salt, g & 2 & 2 & 2 & 2 & 2 \\
\hline Water, g & 60 & 30 & - & 30 & - \\
\hline T fraction, g & - & 30 & 60 & - & - \\
\hline P fraction, g & - & - & - & 30 & 60 \\
\hline $\begin{array}{l}\text { TPC, mg GAE/g d.m. } \\
\text { (after fraction addition) }\end{array}$ & 1.1 & 1.8 & 2.9 & 4.6 & 7.5 \\
\hline
\end{tabular}

Bread C: control bread, no tea fraction addition; Bread 3T (or 3P): $\mathrm{T}(\mathrm{P})$ fraction : water ratio $=1$ : 1; Bread 6T (or 6P): only $\mathrm{T}(\mathrm{P})$ fraction addition

Table 2 Effect of tea fractions on Mixolab properties of flour

\begin{tabular}{lllllll}
\hline Sample & $\begin{array}{l}\text { Development } \\
\text { time, min }\end{array}$ & $\begin{array}{l}\text { Stability time, } \\
\text { min }\end{array}$ & $\mathrm{C} 2, \mathrm{Nm}$ & $\mathrm{C} 3, \mathrm{Nm}$ & $\mathrm{C} 4, \mathrm{Nm}$ & $\mathrm{C} 5, \mathrm{Nm}$ \\
\hline Control & $3.77 \pm 0.17^{\mathrm{d}}$ & $7.33 \pm 0.04^{\mathrm{c}}$ & $0.29 \pm 0.01^{\mathrm{c}}$ & $1.64 \pm 0.01^{\mathrm{b}}$ & $1.45 \pm 0.03^{\mathrm{c}}$ & $2.26 \pm 0.03^{\mathrm{d}}$ \\
$3 \mathrm{~T}$ & $4.10 \pm 0.05^{\mathrm{d}}$ & $6.07 \pm 0.12^{\mathrm{d}}$ & $0.28 \pm 0.01^{\mathrm{c}}$ & $1.65 \pm 0.01^{\mathrm{b}}$ & $1.52 \pm 0.02^{\mathrm{b}}$ & $2.57 \pm 0.04^{\mathrm{b}}$ \\
$6 \mathrm{~T}$ & $4.77 \pm 0.08^{\mathrm{c}}$ & $5.50 \pm 0.09^{\mathrm{e}}$ & $0.23 \pm 0.02^{\mathrm{d}}$ & $1.67 \pm 0.02^{\mathrm{b}}$ & $1.59 \pm 0.01^{\mathrm{a}}$ & $2.84 \pm 0.03^{\mathrm{a}}$ \\
$3 \mathrm{P}$ & $7.12 \pm 0.21^{\mathrm{b}}$ & $8.49 \pm 0.31^{\mathrm{b}}$ & $0.33 \pm 0.01^{\mathrm{b}}$ & $1.71 \pm 0.02^{\mathrm{a}}$ & $1.48 \pm 0.02^{\mathrm{bc}}$ & $2.39 \pm 0.05^{\mathrm{c}}$ \\
6P & $8.69 \pm 0.12^{\mathrm{a}}$ & $10.33 \pm 0.10^{\mathrm{a}}$ & $0.40 \pm 0.02^{\mathrm{a}}$ & $1.73 \pm 0.01^{\mathrm{a}}$ & $1.51 \pm 0.01^{\mathrm{b}}$ & $2.52 \pm 0.01^{\mathrm{b}}$ \\
\hline
\end{tabular}

Values are means \pm standard deviation $(n=3$ determinations). Values of the same column with different letters are significantly different $(p<0.05)$

Control: no tea fraction; 3T (or 3P): $\mathrm{T}(\mathrm{P})$ fraction : water ratio $=1: 1 ; 6 \mathrm{~T}$ (or 6P): only $\mathrm{T}(\mathrm{P})$ fraction addition

C2: protein weakening; C3: starch gelatinization, C4: starch gel stability; C5: starch retrogradation 
Table 3 Effect of tea fractions on the physical parameters (volume, porosity, colour and image analysis), moisture content and TPC of breads

\begin{tabular}{|c|c|c|c|c|c|}
\hline Characteristics & $\mathrm{C}$ & $3 \mathrm{~T}$ & $6 \mathrm{~T}$ & $3 \mathrm{P}$ & $6 \mathrm{P}$ \\
\hline $\begin{array}{l}\text { Volume } \\
\left(\mathrm{cm}^{3} / 100 \mathrm{~g}\right)\end{array}$ & $585 \pm 1^{\mathrm{a}}$ & $573 \pm 5^{\mathrm{a}}$ & $535 \pm 4^{c}$ & $557 \pm 1^{\mathrm{b}}$ & $500 \pm 3^{\mathrm{d}}$ \\
\hline $\begin{array}{l}\text { Crumb } \\
\text { porosity (\%) }\end{array}$ & $89.90 \pm 0.14^{\mathrm{a}}$ & $89.40 \pm 0.42^{\mathrm{a}}$ & $89.60 \pm 0.28^{a}$ & $87.14 \pm 0.08^{b}$ & $85.93 \pm 0.10^{c}$ \\
\hline $\mathrm{L}^{*}$ & $76.66 \pm 0.40^{\mathrm{a}}$ & $62.48 \pm 0.22^{\mathrm{b}}$ & $59.77 \pm 0.21^{\mathrm{c}}$ & $44.24 \pm 0.16^{\mathrm{d}}$ & $38.72 \pm 0.12^{\mathrm{e}}$ \\
\hline$a^{*}$ & $-0.79 \pm 0.03^{\mathrm{e}}$ & $2.67 \pm 0.02^{d}$ & $4.15 \pm 0.02^{\mathrm{c}}$ & $7.52 \pm 0.04^{\mathrm{b}}$ & $9.15 \pm 0.05^{\mathrm{a}}$ \\
\hline$b^{*}$ & $19.16 \pm 0.05^{\mathrm{c}}$ & $19.91 \pm 0.06^{\mathrm{b}}$ & $21.64 \pm 0.06^{\mathrm{a}}$ & $17.96 \pm 0.06^{\mathrm{d}}$ & $17.81 \pm 0.06^{\mathrm{e}}$ \\
\hline $\begin{array}{l}\text { Cell density } \\
\left(\text { no. cells } / \mathrm{cm}^{2}\right)\end{array}$ & $22.8 \pm 0.6^{\mathrm{a}}$ & $20.7 \pm 0.6^{\mathrm{ab}}$ & $18.4 \pm 0.5^{\mathrm{bc}}$ & $16.2 \pm 0.5^{\mathrm{cd}}$ & $15.0 \pm 0.8^{\mathrm{d}}$ \\
\hline $\begin{array}{l}\text { Average cell } \\
\text { size }\left(\mathrm{mm}^{2}\right)\end{array}$ & $1.7 \pm 0.3^{b}$ & $1.4 \pm 0.1^{\mathrm{cb}}$ & $1.1 \pm 0.1^{\mathrm{c}}$ & $1.6 \pm 0.1^{\mathrm{cb}}$ & $2.2 \pm 0.1^{\mathrm{a}}$ \\
\hline $\begin{array}{l}\text { Cell } \\
\text { uniformity }\end{array}$ & $23.3 \pm 0.7^{\mathrm{a}}$ & $14.9 \pm 0.3^{\mathrm{b}}$ & $23.1 \pm 0.4^{\mathrm{a}}$ & $13.1 \pm 0.1^{\mathrm{c}}$ & $12.4 \pm 0.1^{\mathrm{c}}$ \\
\hline Moisture (\%) & $44.8 \pm 0.4^{\mathrm{a}}$ & $44.6 \pm 0.1^{\mathrm{a}}$ & $44.5 \pm 0.4^{\mathrm{a}}$ & $44.2 \pm 0.1^{\mathrm{a}}$ & $44.3 \pm 0.4^{\mathrm{a}}$ \\
\hline $\begin{array}{l}\text { TPC (mg } \\
\text { GAE/g d.m.) }\end{array}$ & $0.5 \pm 0^{\mathrm{e}}$ & $1.2 \pm 0.1^{\mathrm{d}}$ & $1.9 \pm 0.2^{\mathrm{c}}$ & $3.1 \pm 0.1^{\mathrm{b}}$ & $4.9 \pm 0.1^{\mathrm{a}}$ \\
\hline
\end{tabular}

Values are means \pm standard deviation $(n=3$ determinations for volume, porosity, cell density, average cell size, cell uniformity, moisture and TPC; $\mathrm{n}=10$ determinations for colour parameters Values in the same row followed by different superscript letters are significantly different at $p<$ 0.05

Table 4 Enthalpy values (J/g) of bread crumbs stored for different days as measured by DSC

\begin{tabular}{llllll}
\hline Bread & Day 0 & Day 2 & Day 4 & Day 6 & Day 8 \\
\hline $\mathrm{C}$ & $0.60 \pm 0.03^{\mathrm{aC}}$ & $2.85 \pm 0.07^{\mathrm{aB}}$ & $3.48 \pm 0.04^{\mathrm{aA}}$ & nd & nd \\
$3 \mathrm{~T}$ & $0.57 \pm 0.04^{\mathrm{aC}}$ & $2.75 \pm 0.07^{\mathrm{aB}}$ & $3.30 \pm 0.14^{\mathrm{aA}}$ & nd & nd \\
$6 \mathrm{~T}$ & $0.50 \pm 0.01^{\mathrm{aD}}$ & $2.68 \pm 0.11^{\mathrm{aC}}$ & $3.21 \pm 0.05^{\mathrm{aB}}$ & $3.61 \pm 0.06^{\mathrm{aA}}$ & nd \\
$3 \mathrm{P}$ & $0.41 \pm 0.01^{\mathrm{bE}}$ & $2.29 \pm 0.02^{\mathrm{bD}}$ & $2.90 \pm 0^{\mathrm{bC}}$ & $3.48 \pm 0.04^{\mathrm{aB}}$ & $3.63 \pm 0.01^{\mathrm{aA}}$ \\
$6 \mathrm{P}$ & $0.31 \pm 0^{\mathrm{cE}}$ & $2.13 \pm 0.04^{\mathrm{bD}}$ & $2.45 \pm 0.07^{\mathrm{CC}}$ & $3.35 \pm 0.07^{\mathrm{bB}}$ & $3.66 \pm 0.03^{\mathrm{aA}}$ \\
\hline
\end{tabular}

Mean value of duplicate determinations \pm standard deviation a-c: Values within columns with different letter are significantly different $(p<0.05)$ A-E: Values within rows with different letter are significantly different $(p<0.05)$ nd: not determined 
(a)

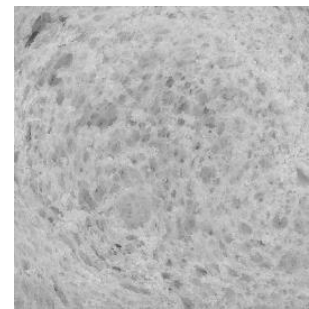

(b)

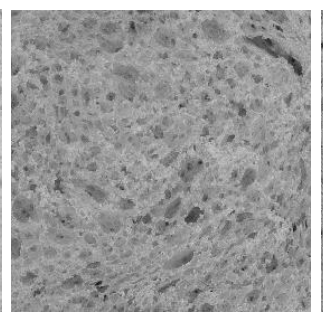

(c)

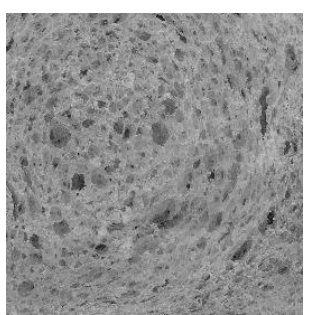

(d)

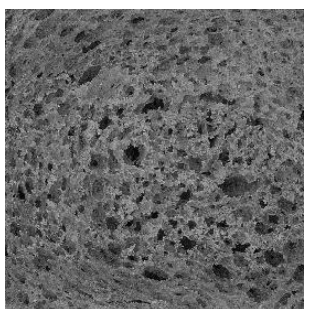

(e)

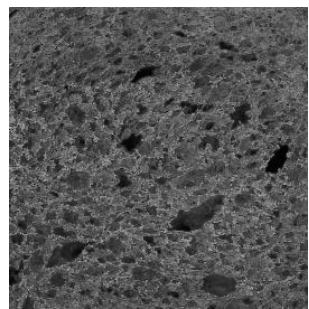

Fig. 1 Crumb gray scale digital images of the center slices of bread. (a) control; (b) 3T; (c) 6T; (d) $3 \mathrm{P}$ and (e) $6 \mathrm{P}$ breads 

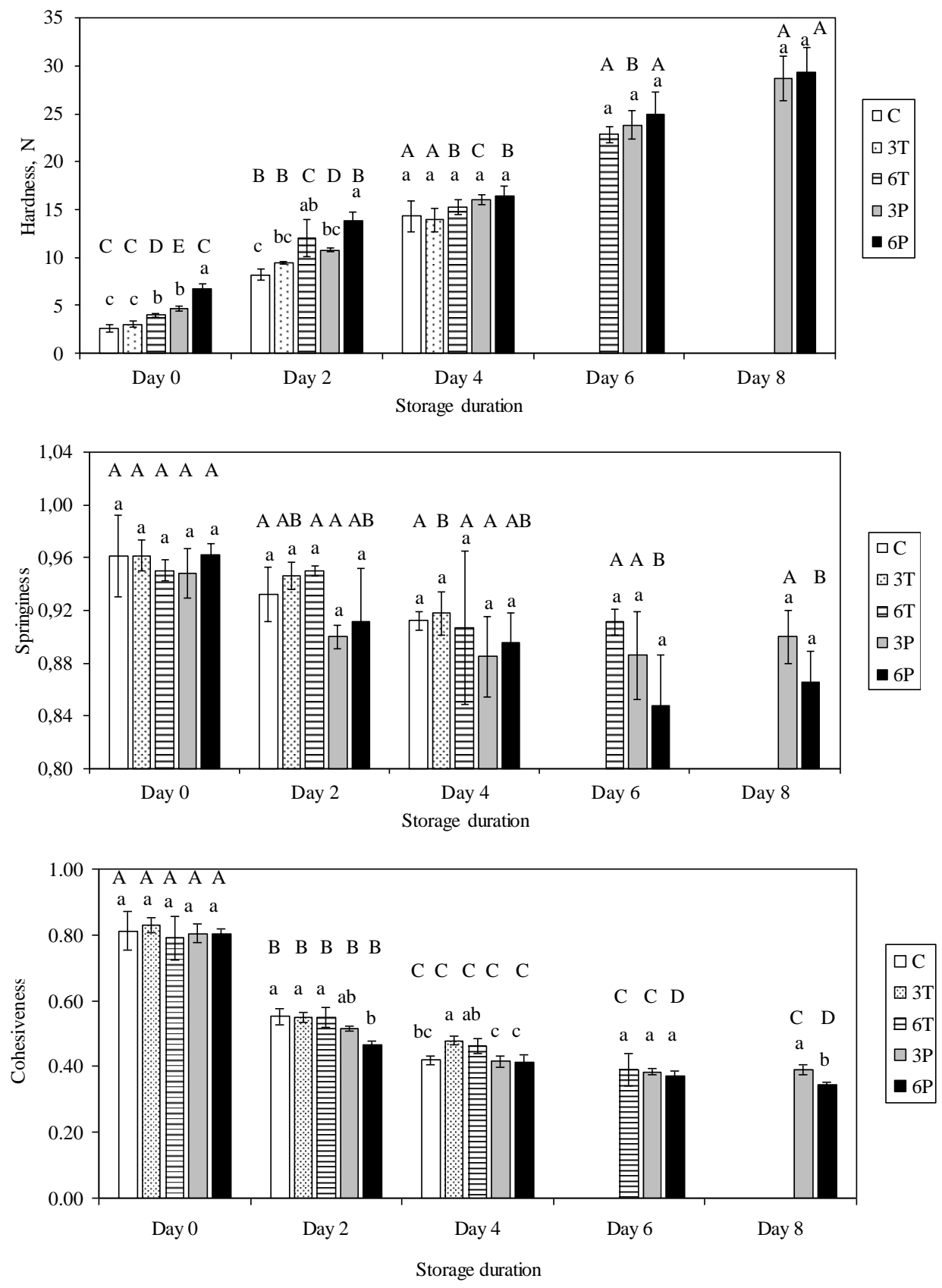


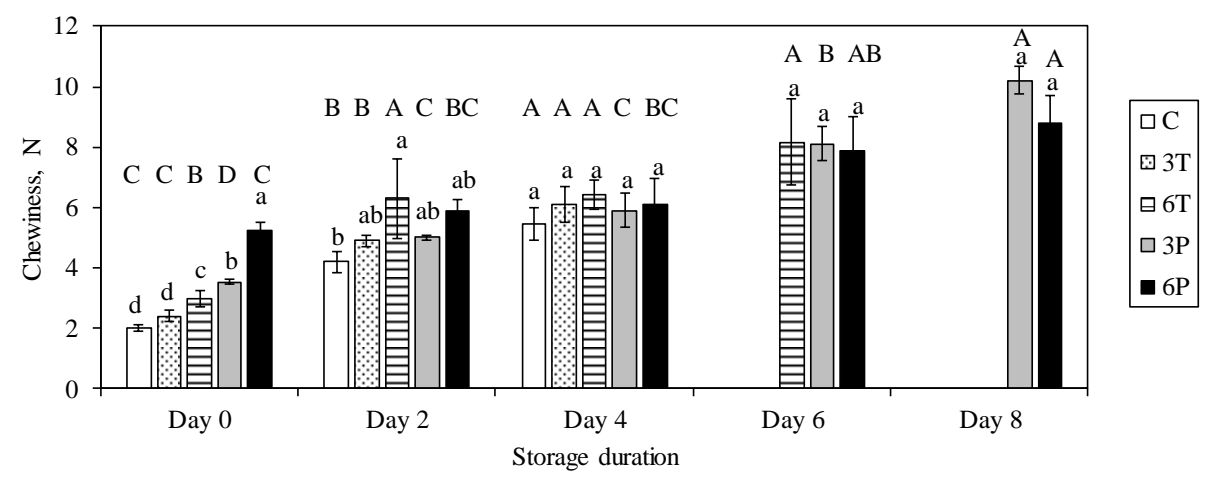

Fig. 2 Changes in hardness, springiness, cohesiveness and chewiness of the bread crumbs over storage. Values labelled with different lowercase letter are significantly different within samples on the same day of storage $(p<0.05)$. Values labelled with different uppercase letter are significantly different within the same type of bread type over storage $(p<0.05)$ 
(a)

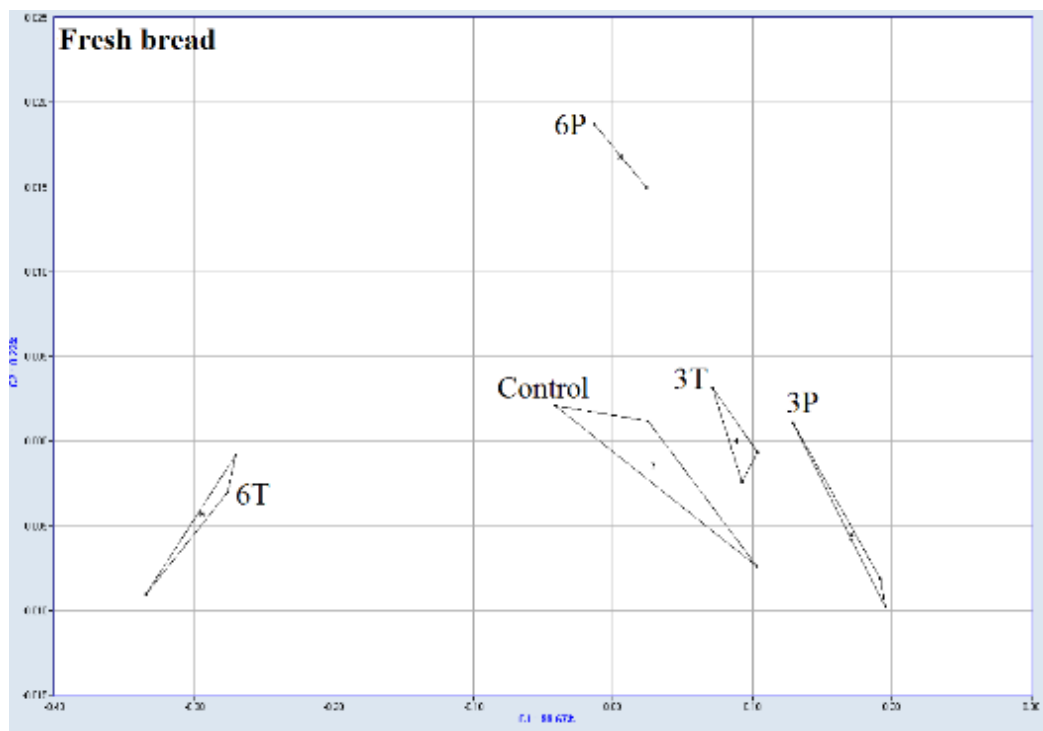

(b)

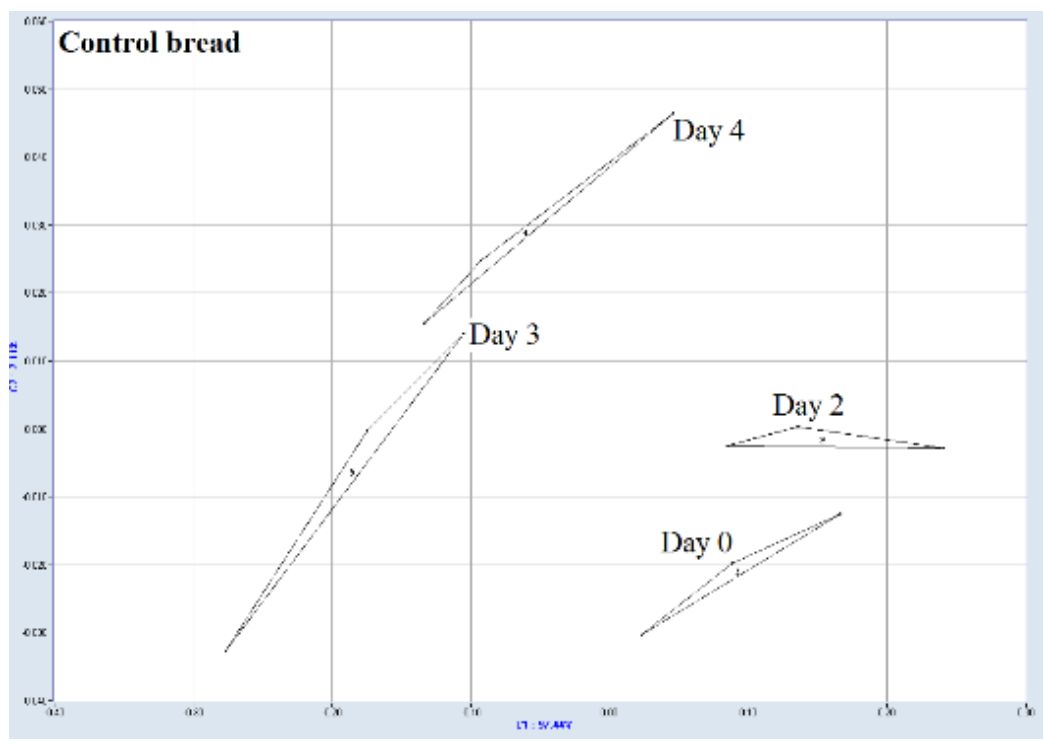




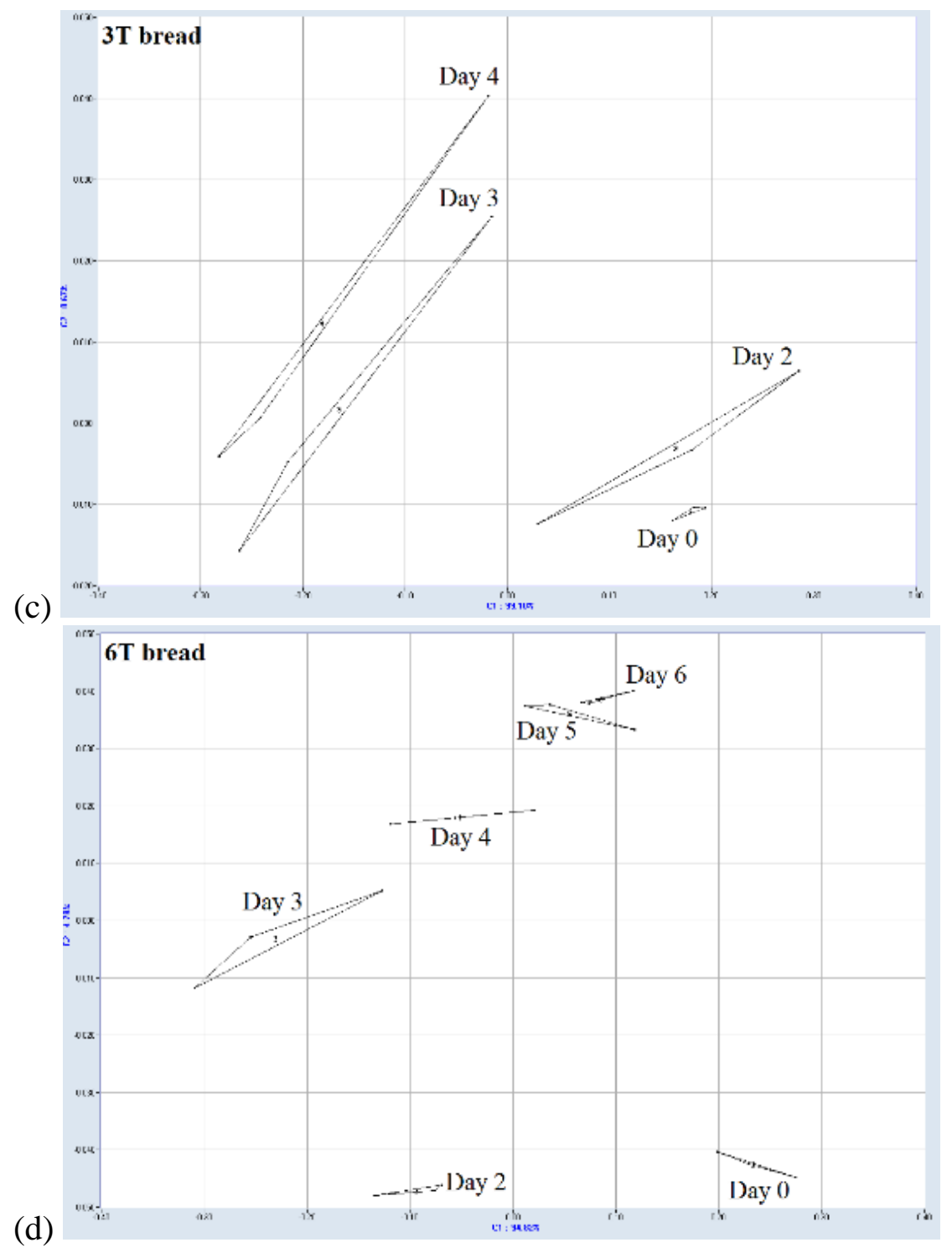




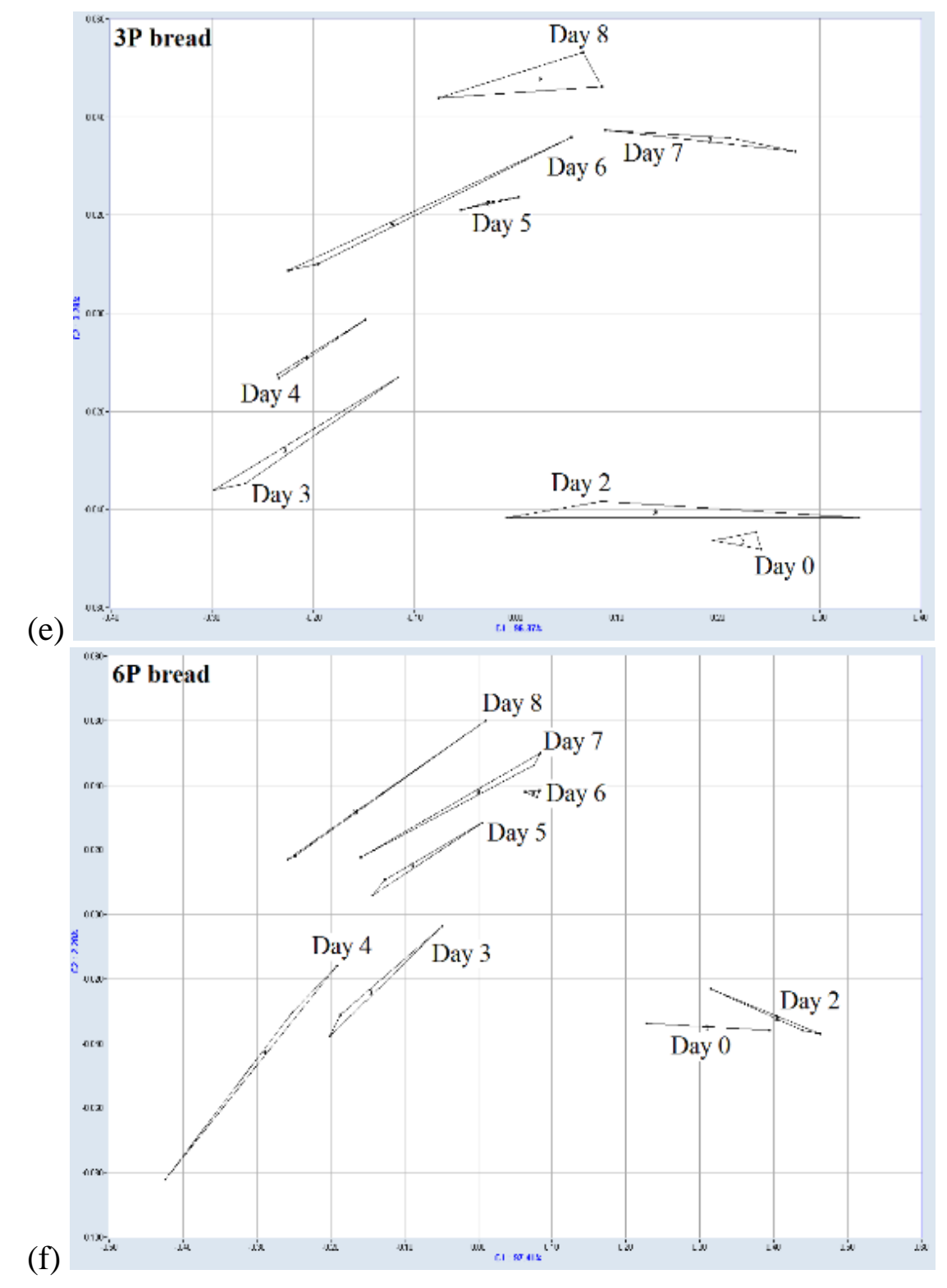




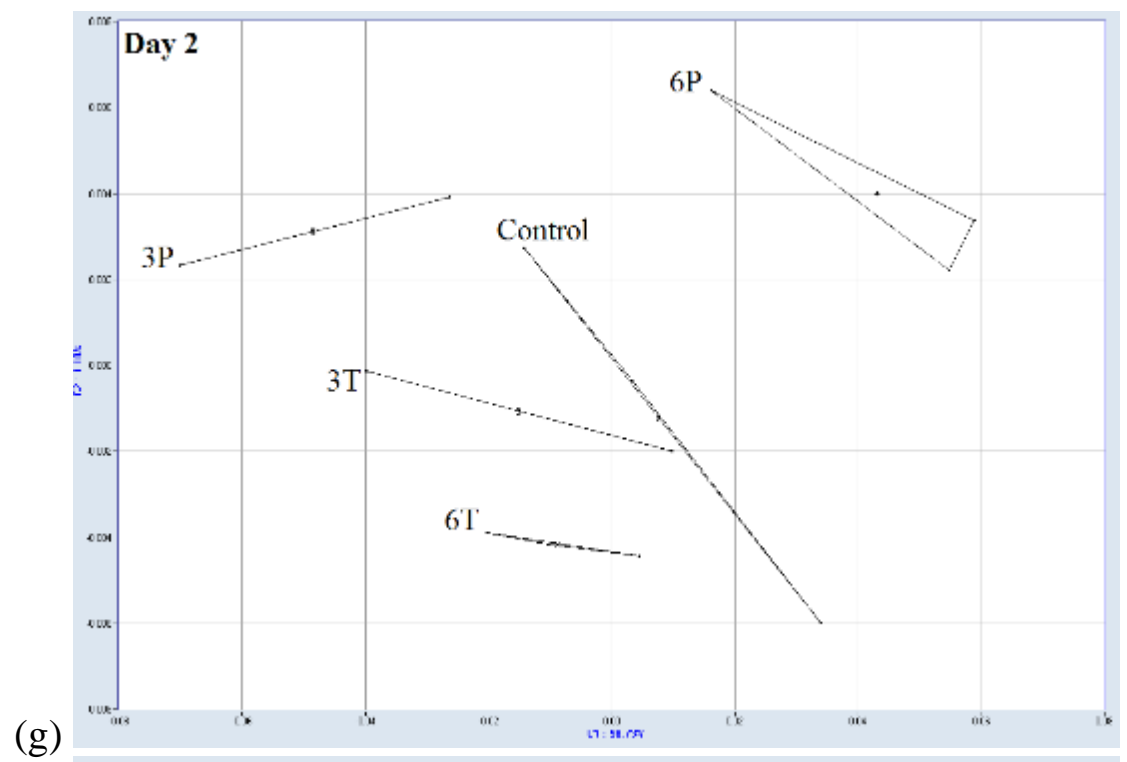

(g)

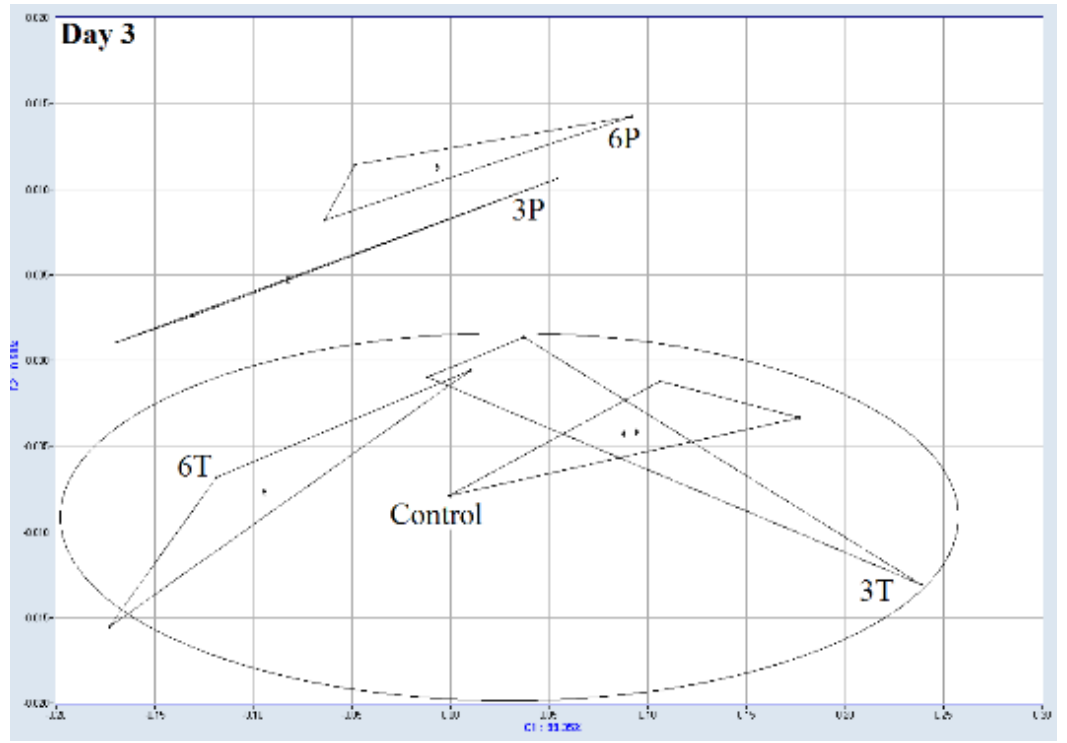

(h) 


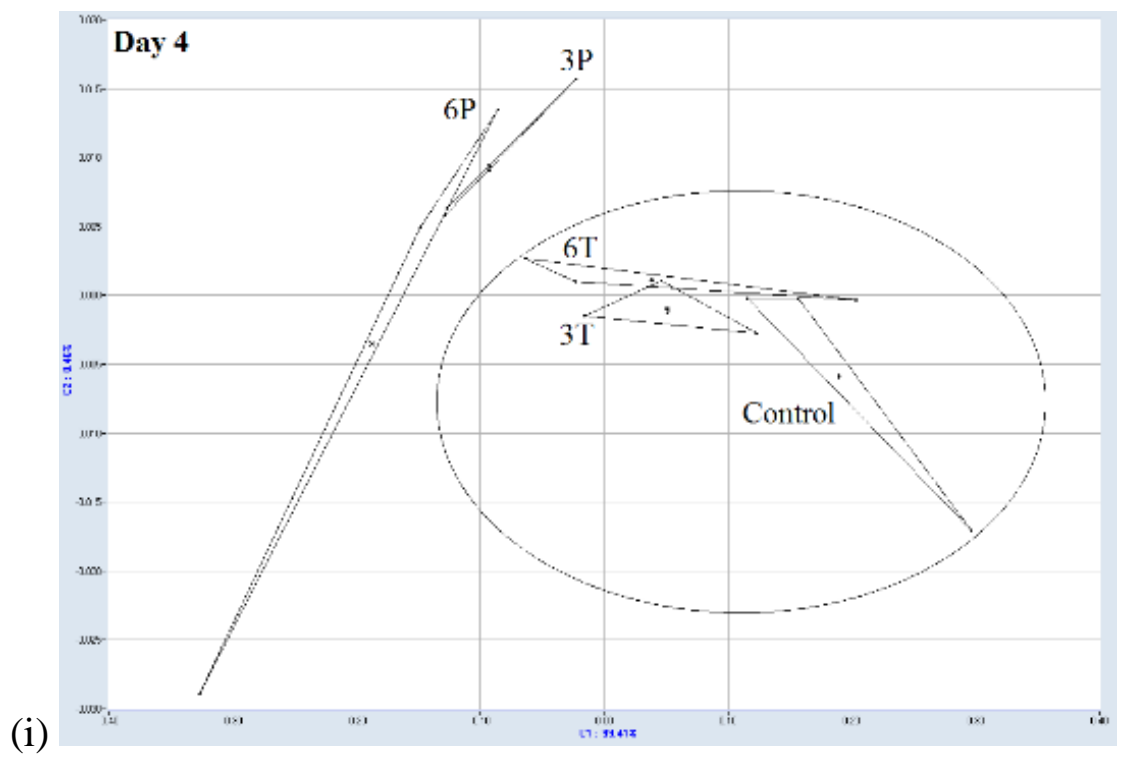

Fig. 3 Odour map of bread samples based on PCA: (a) fresh breads; (b) control bread stored for different days; (c) 3T bread stored for different days; (d) 6T bread stored for different days; (e) 3P bread stored for different days; (f) 6P bread stored for different days; (g) bread stored for 2 days; (h) bread stored for 3 days; (i) bread stored for 4 days 